\title{
Disseminated herpes zoster in the course of chronic myeloid leukemia
}

\section{Rozsiany półpasiec w przebiegu przewlekłej białaczki szpikowej}

\author{
Dorota Artyszuk', Maciej Rogowski', Anna Baran², Iwona Flisiak²
}

'Student Scientific Association at the Department of Dermatology and Venereology, Medical University in Bialystok, Poland

${ }^{2}$ Department of Dermatology and Venereology of the Medical University in Bialystok, Poland

Studenckie Koło Naukowe przy Klinice Dermatologii i Wenerologii, Uniwersytet Medyczny w Białymstoku, Polska

${ }^{2}$ Klinika Dermatologii i Wenerologii, Uniwersytet Medyczny w Białymstoku, Polska

Dermatol Rev/Przegl Dermatol 2021, 108, 194-201

DOI: https://doi.org//0.51/4/dr.2021.108612

\author{
CORRESPONDING AUTHOR/ \\ AUTOR DO KORESPONDENCJI: \\ dr hab. n. med. Anna Baran \\ Klinika Dermatologii \\ i Wenerologii \\ Uniwersytet Medyczny \\ w Białymstoku \\ tel.: +48 857409574 \\ e-mail: anna.baran@umb.edu.pl
}

\begin{abstract}
Introduction: Disseminated herpes zoster often occurs in patients with a history of primary varicella zoster virus infection and impaired immune response. The disease may lead to development of severe complications.

Case report: A 73-year-old man was admitted to the Department of Dermatology due to numerous vesicles on an erythematous background, demonstrating a linear pattern, accompanied by neuralgia, which initially appeared on the left arm and forearm. He had been previously diagnosed with chronic myeloid leukemia. After a few days, changes became generalized. Laboratory tests shown elevated levels of inflammatory markers and thrombocytopenia. Disseminated herpes zoster was diagnosed. The applied therapy resulted in gradual clinical improvement. The patient was referred for further diagnostics and hematological treatment.

Conclusions: Zoster is usually mild. However, it may be the first symptom of chronic disease or malignancy, and especially of lymphoproliferative diseases. Detailed diagnostics is therefore crucial, as the latent form may lead to various complications, not only dermatological, but also of systemic nature.
\end{abstract}

\section{STRESZCZENIE}

Wprowadzenie: Rozsiana forma półpaśca często występuje u pacjentów z wywiadem pierwotnej infekcji VZV (varicella zoster virus) oraz z upośledzoną odpowiedzią immunologiczną i może prowadzić do rozwoju ciężkich powikłań.

Opis przypadku: Mężczyzna 73-letni, w trakcie diagnostyki przewlekłej białaczki szpikowej, został przyjęty do Kliniki Dermatologii z powodu licznych pęcherzyków na rumieniowym podłożu, o linijnym układzie, z towarzyszącą neuralgią, które początkowo pojawiły się na lewym ramieniu i przedramieniu. Po kilku dniach zmiany się uogólniły. Wyniki badań laboratoryjnych wykazały podwyższone stężenia wskaźników stanu zapalnego oraz trombocytopenię. Rozpoznano rozsianą postać półpaśca. Zastosowana terapia przyniosła stopniową poprawę kliniczną. Pacjent został skierowany do dalszej diagnostyki i leczenia hematologicznego. 
Wnioski: Półpasiec ma zazwyczaj łagodny przebieg, jednak może być pierwszym objawem przewlekłej choroby lub nowotworów, szczególnie chorób limfoproliferacyjnych. Istotna jest szczegółowa diagnostyka, ponieważ utajona forma może prowadzić do różnych powikłań, nie tylko dermatologicznych, lecz także układowych.

Key words: disseminated herpes zoster, varicella zoster virus, chronic myeloid leukemia.

Słowa kluczowe: półpasiec rozsiany, wirus ospy wietrznej i półpaśca, przewlekła białaczka szpikowa.

\section{INTRODUCTION}

Zoster is an acute infectious viral disease caused by the varicella zoster virus (VZV) and is characterized by serous vesicles, usually on an erythematous background, that may be clustered or scattered around the affected dermatome. Skin eruptions are often preceded by the occurrence of pain and hyperalgesia $[1,2]$. Herpes zoster eruptions are usually unilateral, however, a disseminated form may develop, which affects $40 \%$ of non-immunocompetent patients, most often the elderly, with diabetes, malignancies, transplant patients and those undergoing chemotherapy $[2,3]$. In most cases, disseminated zoster is characterized by lesions initially limited to one or several dermatomes, and dissemination of lesions occurs on average after 4 days. The generalized form is characterized by the presence of 20 or more vesicles occupying more than two dermatomes, spreading beyond the primary area. In recurrent herpes zoster, and especially in the disseminated form, complications may develop, most often in the form of pneumonia, encephalitis and hepatitis [4].

\section{CASE REPORT}

A 73-year-old man with a history of enlargement of peripheral lymph nodes for 1 year, after recovering from pneumonia 3 months earlier and with weight loss of more than $20 \mathrm{~kg}$ in the last 3 months, was hospitalized for several days in the Department of Hematology, where he was diagnosed for chronic proliferative bone marrow disease. In a family history, one of the patient's brothers died of acute myeloid leukemia. During hospitalization, numerous vesicles on erythematous background appeared in the skin area of the left upper limb. Vesicles were arranged in a linear pattern, filled with serosanguineous content (fig. 1). After 3 days, lesions disseminated. The patient was transferred to the Department of Dermatology for treatment. On admission,

\section{WPROWADZENIE}

Półpasiec jest ostrą, wirusową chorobą zakaźną, wywoływaną przez wirus ospy wietrznej i półpaśca (varicella zoster virus - VZV) i charakteryzującą się występowaniem surowiczych pęcherzyków, zwykle na rumieniowym podłożu, które mogą być zgrupowane lub rozsiane $\mathrm{w}$ obrębie zajmowanego dermatomu. Często zmiany skórne poprzedzone są występowaniem bólu i przeczulicy [1, 2]. Wykwity w przebiegu półpaśca mają zazwyczaj układ jednostronny, jednak może dojść do rozwoju postaci rozsianej, która dotyczy 40\% pacjentów immunoniekompetentnych, najczęściej osób starszych, z cukrzycą, nowotworami złośliwymi, chorych po przeszczepieniach narządów, jak również poddawanych chemoterapii $[2,3]$. W większości przypadków półpasiec rozsiany charakteryzują zmiany chorobowe początkowo ograniczone do jednego lub kilku dermatomów, średnio po 4 dniach dochodzi do rozsiewu zmian. Forma uogólniona cechuje się występowaniem 20 lub większej liczby pęcherzyków zajmujących więcej niż dwa dermatomy, szerzące się poza obszarem pierwotnym. W nawrotach półpaśca oraz szczególnie w postaci rozsianej może dochodzić do rozwoju powikłań, najczęściej w postaci zapalenia płuc, mózgu i wątroby [4].

\section{OPIS PRZYPADKU}

Mężczyzna 73-letni był hospitalizowany w Klinice Hematologii z wywiadem powiększenia obwodowych węzłów chłonnych od roku, po przebytym zapaleniu płuc 3 miesiące wcześniej oraz z utratą masy ciała ponad $20 \mathrm{~kg}$. W czasie hospitalizacji prowadzono diagnostykę w kierunku przewlekłej choroby rozrostowej szpiku. W wywiadzie rodzinnym jeden z braci pacjenta zmarł z powodu ostrej białaczki szpikowej. W trakcie hospitalizacji w obrębie skóry kończyny górnej lewej pojawiły się liczne pęcherzy- 


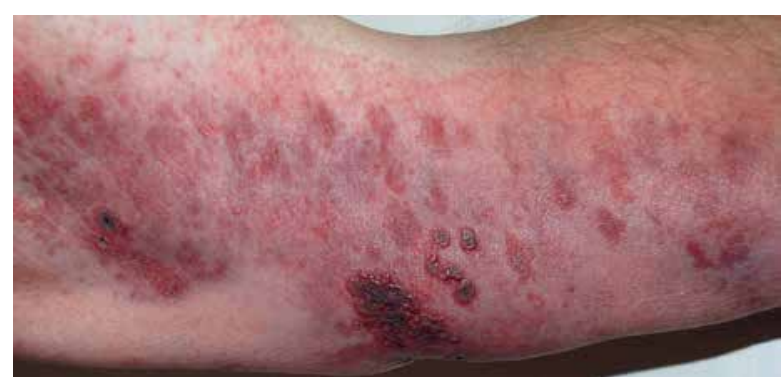

Figure I. Multiple vesicles filled with serosanguineous fluid on erythematous base arranged in a linear pattern on the skin of left upper limb

Rycina I. Liczne pęcherzyki wypełnione treścią surowiczo-krwistą na rumieniowym podłożu układające się linijnie w obrębie skóry kończyny górnej lewej

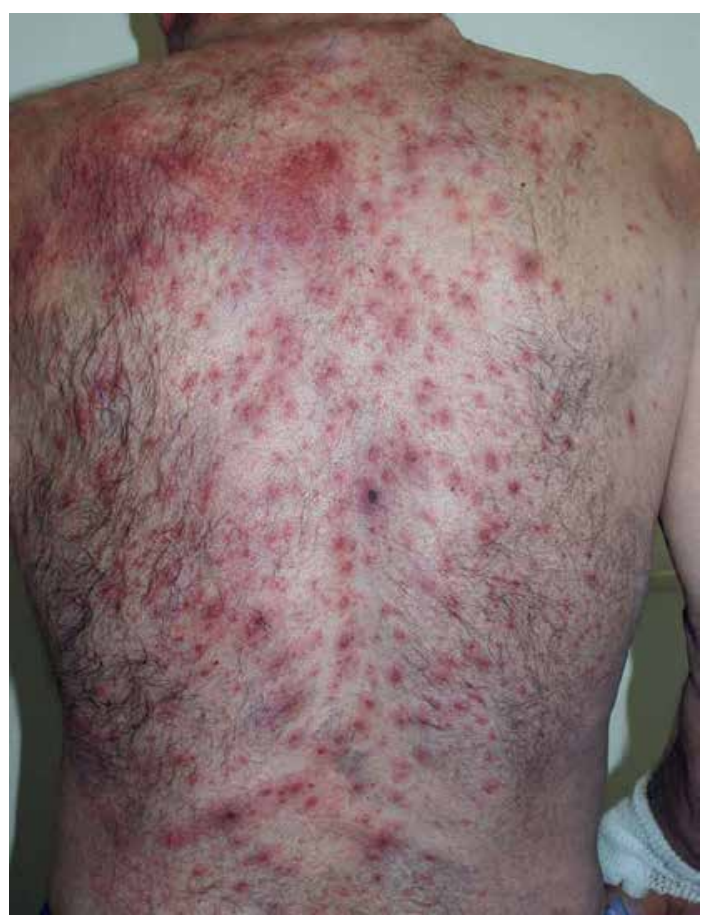

Figure 3. Multiple erythematous infiltrated plaques, vesicles and erosions on the back

Rycina 3. Liczne zmiany rumieniowo-naciekowe oraz pęcherzyki i nadżerki w obrębie skóry pleców

numerous vesicles, erythematous-edematous lesions, erosions, hemorrhagic crusts accompanied by pain and hyperesthesia, increased body temperature up to $38^{\circ} \mathrm{C}$ and enlarged peripheral lymph nodes (figs. 2-4). Laboratory tests demonstrated an increased C-reactive protein level - $91.4 \mathrm{mg} / \mathrm{dl}$ (normal range: 0-5 mg/dl), white blood cells $(\mathrm{WBC}) 74.08 \times 10^{9} / 1$ (normal range: 4.23-9.07), thrombocytopenia - $46 \times 10^{9} / 1$ (normal range: 163-337). A microscopic smear demonstrated lymphocytes - 97\%, stimulated lymphocytes - 3\%, numerous shadows of scattered cells. Chest X-ray showed widened hili, with polycyclic outlines - nodal, and dilated and elongated aorta. The abdominal ultrasound

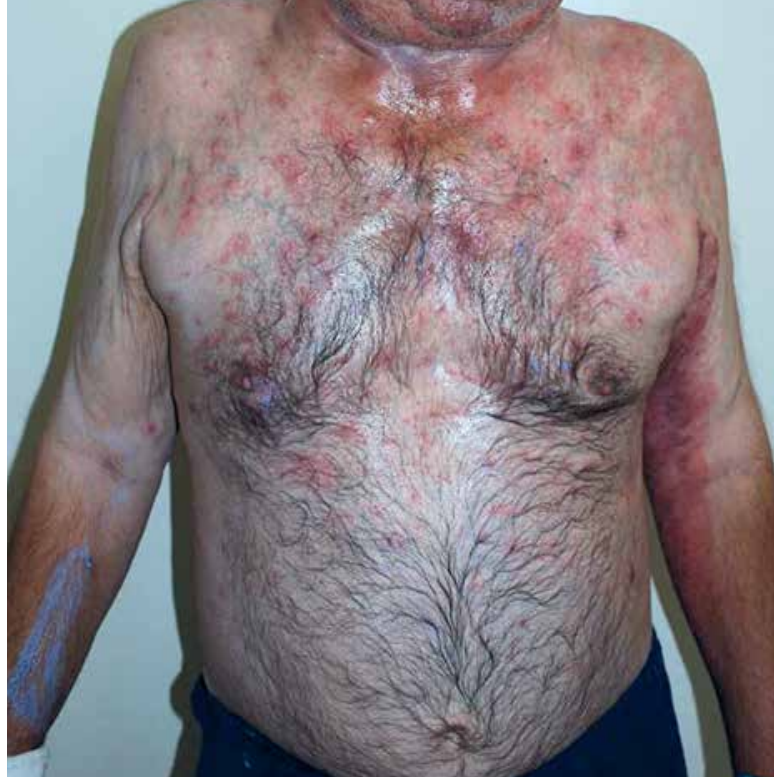

Figure 2. Multiple erythematous infiltrated plaques, vesicles and erosions on the scalp, face and abdomen

Rycina 2. Liczne zmiany rumieniowo-naciekowe oraz pęcherzyki i nadżerki w obrębie skóry owłosionej głowy, twarzy i brzucha

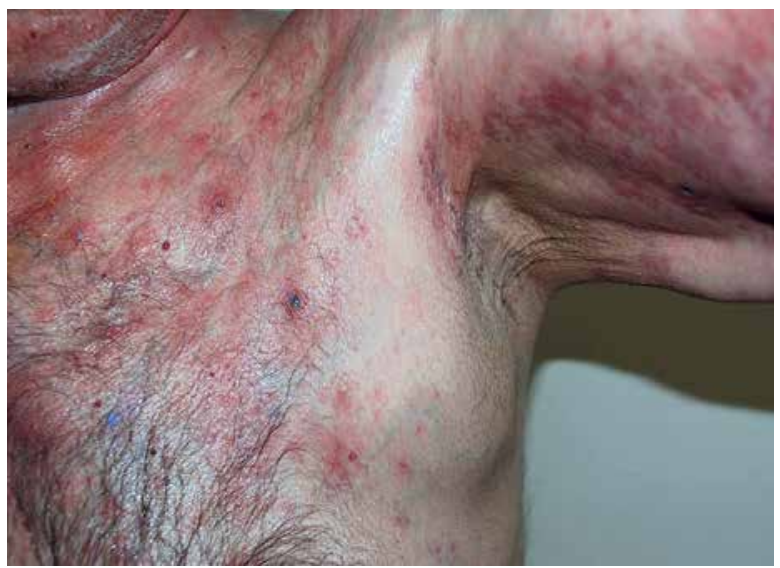

Figure 4. Enlarged axillary lymph nodes. Erosions after ruptured vesicles on an erythematous-edematous background

Rycina 4. Powiększone węzły chłonne pachowe. Nadżerki po pękniętych pęcherzykach na rumieniowo-obrzękowym podłożu

ki na rumieniowym podłożu, układające się linijnie, wypełnione treścią surowiczo-krwistą (ryc. 1). Po 3 dniach doszło do rozsiewu zmian skórnych. Pacjenta przeniesiono do Kliniki Dermatologii w celu leczenia. Przy przyjęciu stwierdzono w obrębie skóry owłosionej głowy, twarzy, pleców, częściowo brzucha i kończyn dolnych liczne pęcherzyki, zmiany rumieniowo-obrzękowe, nadżerki, krwotoczne strupy, którym towarzyszył ból i przeczulica, podwyższona temperatura ciała do $38^{\circ} \mathrm{C}$ oraz powiększone obwodowe węzły chłonne (ryc. 2-4). $\mathrm{W}$ badaniach laboratoryjnych z odchyleń stwierdzono podwyższone stężenie białka C-reaktywne- 


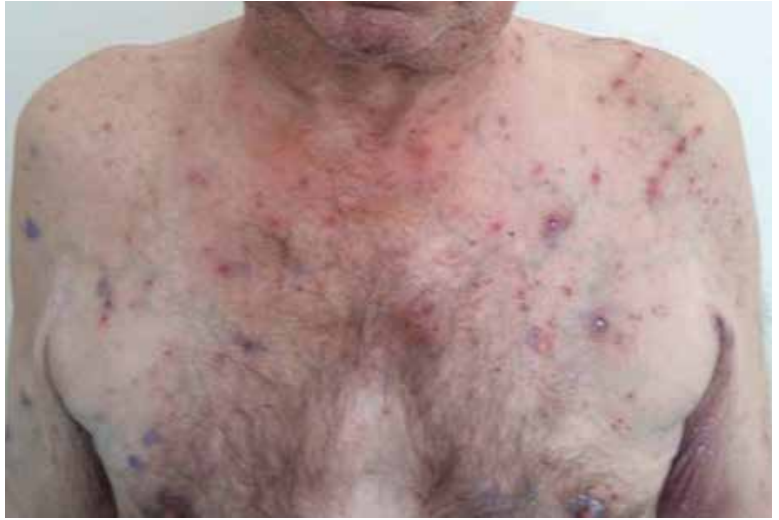

Figure 5. Patient's condition after 10 days of treatment

Rycina 5. Stan po 10 dniach leczenia

showed enlarged liver, spleen and numerous enlarged lymph nodes in the retroperitoneal space. Based on the clinical presentation of dermatosis, a diagnosis of disseminated herpes zoster was made. Intravenous acyclovir at the dose of $3 \times 500 \mathrm{mg}$ was used in the treatment. Intravenous antibiotic therapy was continued (piperacillin with tazobactam) and topical preparations (liquid powder, pyoctane, acyclovir). During the ten-day hospitalization, a gradual clinical improvement was observed (figs. 5,6). The patient was discharged home as recommended by the consulting hematologist, for further treatment in outpatient setting at the Department of Hematology. Half a year later, the patient was re-admitted to the Department of Hematology because to general weakness, night sweats, and a further loss of $20 \mathrm{~kg}$ within 2 months. Physical examination demonstrated numerous enlarged lymph nodes in packs: cervical, nuchal, supraclavicular, subclavian, axillary, inguinal, as well as enlarged liver and spleen. There were numerous shadows of cells in the peripheral blood smear. Chronic lymphocytic leukemia was diagnosed on the basis of peripheral blood lymphocytosis and the characteristic immunophenotype. Chemotherapy cycles were started.

\section{DISCUSSION}

Zoster occurs in patients in whom the VZV virus remaining in a latent form in ganglion cells of dorsal roots and the ganglia of the cranial nerves becomes reactivated [3]. The clinical presentation of disseminated herpes zoster consists of numerous vesicles filled with serosanguineous content, which may undergo necrosis, usually on an erythematous or erythematous-edematous background. Zoster is classified as disseminated when there are more than 20 vesicles outside the primarily affected area. In $90 \%$ of patients with disseminated herpes zoster, lesions are initially limited to one or several dermatomes, and disseminated lesions appear on average after 4 days (1-12 days) [2]. Similarly,

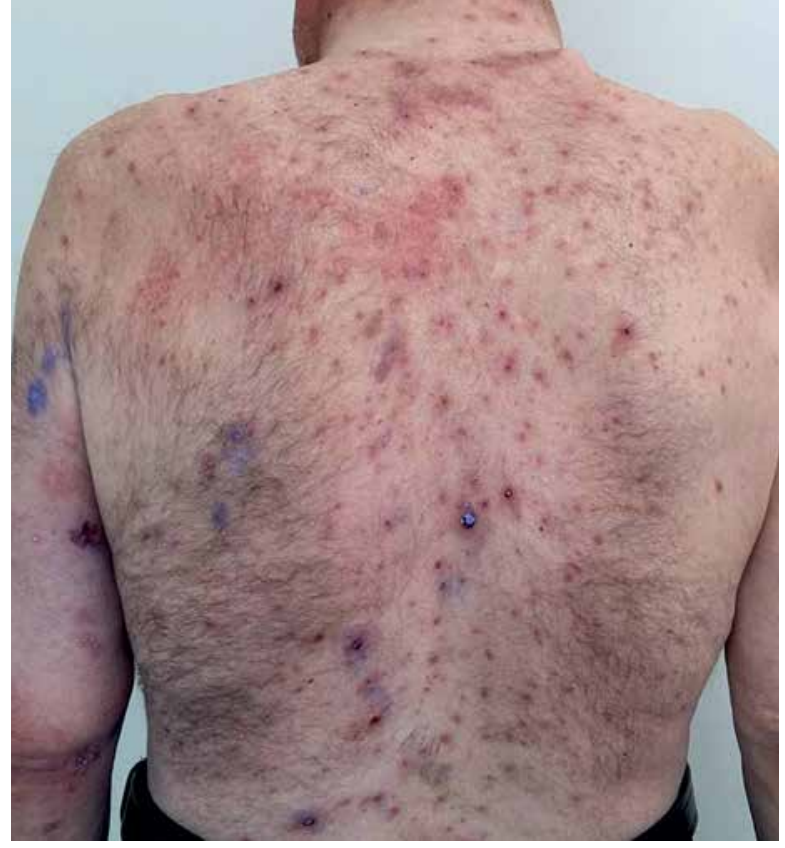

Figure 6. Patient's condition after 10 days of treatment Rycina 6. Stan po 10 dniach leczenia

go - 91,4 mg/dl (norma: 0-5 mg/dl), leukocytów - 74,08 × 109/1 (norma: 4,23-9,07), trombocytopenię - $46 \times 10^{9} / 1$ (norma: 163-337), w rozmazie mikroskopowym stwierdzono limfocyty - 97\%, limfocyty pobudzone - 3\%, liczne cienie roztartych komórek. W badaniu rentgenograficznym (RTG) klatki piersiowej wykazano poszerzone wnęki, o policyklicznych zarysach - węzłowe, poszerzoną i wydłużoną aortę. W badaniu ultrasonograficznym (USG) jamy brzusznej zaobserwowano powiększoną wątrobę, śledzionę oraz liczne powiększone węzły chłonne w przestrzeni zaotrzewnowej. Na podstawie obrazu klinicznego ustalono rozpoznanie półpaśca rozsianego. W leczeniu zastosowano acyklowir dożylnie w dawce $3 \times 500 \mathrm{mg}$, kontynuowano antybiotykoterapię dożylną (piperacylina z tazobaktamem) oraz preparaty miejscowe (puder płynny, pioktanina, acyklowir). W czasie 10-dniowej hospitalizacji obserwowano stopniową poprawę kliniczną (ryc. 5, 6). Pacjenta wypisano do domu zgodnie z zaleceniem konsultującego hematologa do dalszego leczenia ambulatoryjnego w poradni hematologicznej. Pół roku później pacjent został ponownie przyjęty do Kliniki Hematologii z powodu ogólnego osłabienia, nocnych potów, dalszej utraty masy ciała - $20 \mathrm{~kg}$ w czasie 2 miesięcy. W badaniu przedmiotowym stwierdzono liczne powiększone węzły chłonne w pakietach: szyjne, karkowe, nadobojczykowe, podobojczykowe, pachowe, pachwinowe oraz powiększoną wątrobę i śledzionę. W rozmazie krwi obwodowej widoczne były liczne cienie komórek. Na podstawie limfocytozy krwi obwodowej oraz 
in the presented patient, dissemination of changes in the course of herpes zoster occurred 4 days after primary eruptions arranged unilaterally along one dermatome. The main factors increasing the risk of disseminated herpes zoster include: age over 50, especially in the 70-80 age group [1,3], female sex [5] and presence of diseases such as lymphomas and leukemias [6]. Patients undergoing bone marrow transplantation, suffering from AIDS, treated with immunosuppressants on longterm basis, exposed to UV radiation, after splenectomy or about a month after vaccination against chickenpox $[2,6,7]$, with impaired immune system, due to the reduced number and activity of T cells are particularly predisposed. Zoster occurs even 20 to 100 times more often in non-immunocompetent patients (even 40\%), and the coexistence of bone marrow proliferative diseases increases the risk 1.9 times compared to the control group and amounts to $13 \%$ in the case of chronic myeloid leukemia $[8,9]$. Increased incidence of herpes zoster occurs in the group of people suffering from diabetes and arterial hypertension [1]. The risk of developing herpes zoster is more than 5 times higher in patients with lymphoproliferative neoplasms. At the same time, patients with herpes zoster are at increased risk of cancer development $(\mathrm{HR}=1.2)$, especially in the lymphoid tissue $(\mathrm{HR}=1.68-3.4)$. In our patient, the preceding systemic symptoms and the occurrence of disseminated herpes zoster were associated with the underlying disease - chronic lymphocytic leukemia. In patients with bone marrow proliferative disease, disseminated herpes zoster occurs significantly more often after bone marrow transplantation - the incidence is $17-36 \%$ [7, 10]. The literature provides descriptions of patients in whom disseminated herpes zoster coexisted with pain, inadequate vasopressin secretion [11], Ramsay-Hunt syndrome, in which the first bullous lesions appeared behind the eardrum, and in the next day they affected the ear, face and body area [12]. A case of a 51-year-old patient in whom VZV was reactivated due to immunosuppression and a cytokine storm caused by severe burns, covering $60 \%$ of the body surface, was also reported [13]. Another report describes a case of HSV and VZV correlation in a 65-year-old patient, 2 months after the end of the fourth cycle of chemotherapy as a treatment for non-Hodgkin's lymphoma [14]. Disseminated herpes zoster is a disease increasing mortality among hospitalized patients, especially the elderly, undergoing immunosuppressive treatment, with bone marrow proliferative diseases and AIDS [1, 2]. In the presented case, lesions initially appeared on the upper limb, and then they were generalized. The primary localization of disseminated herpes zoster has been described, inter alia, in within the skin around the mastoid process, ear $[4,9,12]$, abdomen [10], groin [8], and lower limbs [15]. The diagnosis is most often made on the basis of medical history and physical examination. It is also pos- charakterystycznego immunofenotypu rozpoznano przewlekłą białaczkę limfocytową. Rozpoczęto cykle chemioterapii.

\section{OMÓWIENIE}

Półpasiec występuje u chorych, u których doszło do reaktywacji, pozostającego $\mathrm{w}$ formie latentnej w komórkach zwojowych korzeni grzbietowych i zwojach nerwów czaszkowych, wirusa VZV [3]. $\mathrm{Na}$ obraz kliniczny półpaśca rozsianego składają się liczne pęcherzyki wypełnione treścią surowiczo-krwistą, które mogą ulegać martwicy, zazwyczaj zlokalizowane na rumieniowym lub rumieniowo-obrzękowym podłożu. Półpasiec jest kwalifikowany jako rozsiany, gdy pojawi się 20 pęcherzyków występujących poza obszarem pierwotnego wykwitu. U $90 \%$ chorych z półpaścem rozsianym zmiany chorobowe są początkowo ograniczone do jednego lub kilku dermatomów, zmiany rozsiane pojawiają się średnio po 4 dniach (1-12 dni) [2]. Podobnie $\mathrm{u}$ przedstawionego pacjenta do rozsiewu zmian w przebiegu półpaśca doszło po 4 dniach od pierwotnych wykwitów układających się jednostronnie wzdłuż jednego dermatomu. Do głównych czynników zwiększających ryzyko rozwoju półpaśca rozsianego należą: wiek powyżej 50 lat, szczególnie 70-80 lat [1, 3], płeć żeńska [5] oraz występowanie chorób, takich jak chłoniaki, białaczki [6]. Predysponowani są pacjenci poddawani procedurze przeszczepienia szpiku kostnego, chorujący na AIDS, poddawani długotrwałej terapii lekami immunosupresyjnymi, ekspozycji na promieniowanie UV, po przebytej splenektomii lub też osoby około miesiąc po szczepieniu przeciwko ospie wietrznej $[2,6,7]$, $\mathrm{z}$ upośledzonym układem odpornościowym, z powodu zmniejszonej liczby oraz aktywności limfocytów T. Półpasiec występuje nawet od 20 do 100 razy częściej u immunoniekompetentnych pacjentów (u nawet $40 \%$ ) niż immunokompetentnych, a współwystępowanie chorób rozrostowych szpiku zwiększa ryzyko 1,9 razy w stosunku do grupy kontrolnej i wynosi $13 \% \mathrm{w}$ przypadku przewlekłej białaczki szpikowej $[8,9]$. Zwiększona zapadalność na półpasiec występuje u chorych na cukrzycę oraz nadciśnienie tętnicze [1]. Ryzyko rozwoju półpaśca jest ponad 5-krotnie podwyższone $\mathrm{u}$ chorych $\mathrm{z}$ nowotworami limfoproliferacyjnymi. Jednocześnie pacjenci z półpaścem mają zwiększone ryzyko rozwoju nowotworów (HR =1,2), zwłaszcza dotyczy to tkanki limfatycznej (HR = 1,68-3,4). U naszego pacjenta poprzedzające objawy ogólnoustrojowe oraz wystąpienie półpaśca rozsianego współtowarzyszyły chorobie zasadniczej - przewlekłej białaczce limfatycznej. U osób z chorobą rozrostową szpiku kostnego półpasiec rozsiany występuje znacząco częściej po 
sible to detect viral DNA using the highly-specific PCR method [14]. However, there are reports indicating that approximately $20 \%$ of test results may be false-negative [12]. Other additional diagnostic methods include: detection of anti-VZV antibodies by fluorescence or peroxidase technique with the use of antibodies, biopsy of skin lesions and the Tzanck smear are taken into account. A characteristic presentation of the smear is intracellular inclusion, formation of multicellular cells, acantholysis, balloon degeneration [15]. Varicella and disseminated HSV infection should be considered in the differentiation of disseminated herpes zoster. Due to the serious prognosis, the therapy should be introduced as soon as possible. Acyclovir $10 \mathrm{mg} / \mathrm{kg}$ body weight is recommended in patients with impaired immunity, after organ transplant, with malignancies or with organ spreading herpes zoster. Acyclovir is administered intravenously every 8 hours for 10 days $[1,8,14]$. Prompt initiation of treatment is particularly important in nonimmunocompetent patients, whose disease is mostly disseminated. This minimizes the risk of spreading the virus and developing generalized visceral zoster [11], which is an immediate life-threatening condition. It also reduces the risk of neuralgia and alleviates pain [6]. There is also a live, attenuated zoster vaccine that is recommended for people over 50 years of age. A 10-year retrospective study based on observation of patients after administration of a total of over 34 million doses has proven its safety and efficacy [16].

\section{CONCLUSIONS}

Zoster in patients with immunodeficiencies is more often of a generalized nature, both in cutaneous and organ forms. Disseminated herpes zoster occurs in $2-10 \%$ of people with normal immunity, and in $40 \%$ of non-immunocompetent patients. In $90 \%$ of patients with disseminated herpes, eruptions are initially limited to one or several dermatomes, disseminated lesions usually appear after a few days. In patients with disseminated disease, it is important to initiate intravenous treatment as soon as possible to prevent the development of immediately life-threatening systemic visceral herpes zoster, alleviate pain and prevent neuralgia.

\section{CONFLICT OF INTEREST}

The authors declare no conflict of interest. przeszczepieniu szpiku kostnego, częstość występowania wynosi 17-36\% [7, 10]. W piśmiennictwie dostępne są opisy pacjentów, u których półpasiec rozsiany współwystępował z bólem, zespołem nieadekwatnego wydzielania wazopresyny [11], oraz zespołem Ramsaya-Hunta, w którym pierwsze zmiany skórne pojawiły się za błoną bębenkową, a w kolejnej dobie zajęły okolicę ucha, twarzy oraz były rozsiane na całej skórze [12]. Opisano również przypadek 51-letniego pacjenta, u którego infekcja VZV uległa reaktywacji wskutek immunosupresji oraz burzy cytokinowej wywołanych ciężkimi oparzeniami, obejmującymi $60 \%$ powierzchni skóry [13]. W innej pracy opisano przypadek koreaktywacji HSV i VZV u 65-letniego pacjenta 2 miesiące po zakończeniu czwartego cyklu chemioterapii w leczeniu chłoniaka nie-Hodgkina [14]. Półpasiec rozsiany jest chorobą zwiększającą śmiertelność wśród hospitalizowanych pacjentów, szczególnie osób starszych, poddanych leczeniu immunosupresyjnemu, z chorobami rozrostowymi szpiku i AIDS [1, 2]. W naszym przypadku zmiany początkowo pojawiły się na kończynie górnej, a następnie się uogólniły. Pierwotną lokalizację półpaśca rozsianego opisywano m.in. w obrębie skóry okolicy wyrostka sutkowatego, ucha [4, 9, 12], brzucha [10], pachwiny [8], kończyn dolnych [15]. Rozpoznanie ustala się najczęściej na podstawie badania przedmiotowego oraz podmiotowego. Możliwe jest dodatkowo badanie DNA wirusa metodą PCR, która cechuje się wysoką specyficznością [14]. Istnieją jednak doniesienia, że w ok. $20 \%$ wynik testu może być fałszywe ujemny [12]. Do innych dodatkowych metod diagnostycznych należą: wykrywanie przeciwciał przeciwko VZV metodą fluorescencji lub technika peroksydazowa z użyciem przeciwciał, biopsja zmian skórnych oraz rozmaz Tzancka. Charakterystyczny obraz rozmazu to: wewnątrzkomórkowa inkluzja, tworzenie wielokomórkowych komórek, akantoliza, zwyrodnienia balonowate [15]. W różnicowaniu półpaśca rozsianego należy uwzględnić ospę wietrzną i rozsianą infekcję HSV. Ze względu na możliwe niekorzystne rokowanie należy niezwłocznie włączyć leczenie ogólne. Pacjentom z upośledzoną odpornością, po przeszczepieniu narządów, z nowotworem złośliwym lub z powikłaniami narządowymi półpaśca zaleca się acyklowir w dawce $10 \mathrm{mg} / \mathrm{kg}$ m.c. podawany dożylnie co 8 godzin przez 10 dni $[1,8,14]$. Szybkie włączenie leczenia jest szczególnie ważne u pacjentów immunoniekompetentnych, u których choroba przyjmuje najczęściej postać rozsianą. Minimalizuje to ryzyko rozsiewu wirusa i rozwinięcie powikłań narządowych [11], który jest stanem bezpośredniego zagrożenia życia. Zmniejsza także ryzyko wystąpienia neuralgii i ogranicza objawy bólowe [6]. Istnieje żywa, atenuowana szczepionka 
przeciw półpaścowi, która jest zalecana osobom powyżej 50. roku życia. Dziesięcioletnie retrospektywne badanie oparte na obserwacji pacjentów po otrzymaniu łącznie ponad 34 milionów dawek dowiodło jej bezpieczeństwa oraz skuteczności [16].

\section{WNIOSK}

Półpasiec u chorych z niedoborami odporności częściej ma charakter uogólniony, zarówno w postaciach skórnych, jak i narządowych. Półpasiec rozsiany występuje u 2-10\% osób z prawidłową odpornością, u $40 \%$ pacjentów immunoniekompetentnych. U $90 \%$ chorych z półpaścem rozsianym zmiany chorobowe są początkowo ograniczone do jednego lub kilku dermatomów, zmiany rozsiane pojawiają się zwykle po kilku dniach. U pacjentów z postacią rozsianą ważne jest jak najszybsze włączenie leczenia przeciwwirusowego dożylnie, aby zapobiec powikłaniom narządowym stanowiącym bezpośrednie zagrożenie życia, złagodzić dolegliwości bólowe i zapobiec neuralgii.

\section{KONFLIKT INTERESÓW}

Autorzy nie zgłaszają konfliktu interesów.

\section{References}

\section{Piśmiennictwo}

1. Baran A., Świstak M., Nowowiejska J., Myśliwiec H., Flisiak I.: Półpasiec - analiza retrospektywna 85 pacjentów. Dermatol Estet 2016, 6, 320-330.

2. Żaba R.: Opryszczka. Półpasiec. Ospa wietrzna. Termedia Wydawnictwa Medyczne, Poznań, 2011.

3. Albrecht P., Patrzałek M., Goryński P.: Zagrożenie półpaścem i jego powikłaniami w Polsce i na świecie w zależności od wieku. Przegl Epidemiol 2015, 69, 841-843.

4. Sutton E., Lopez J.J., Dao L.N., Wetter D.A.: Disseminated herpes zoster in chronic lymphocytic leukemia. J Emerg Med 2016, $50,159-160$.

5. Buchan S.A., Daneman N., Wang J., Garber G., Wormsbecker A.E., Wilson S.E., et al.: Incidence of hospitalizations and emergency department visits for herpes zoster in immunocompromised and immunocompetent adults in Ontario, Canada, 2002-2016. Clin Infect Dis 2020, 71, 22-29.

6. Costa E., Buxton J., Brown J., Templeton K.E., Breuer J., Johannessen I.: Fatal disseminated varicella zoster infection following zoster vaccination in an immunocompromised patient. BMJ Case Rep 2016, 2016, bcr2015212688.

7. Mattiuzzi G.N., Cortes J.E., Talpaz M., Reuben J., Rios M.B., Shan J., et al.: Development of varicella-zoster virus infection in patients with chronic myelogenous leukemia treated with imatinib mesylate. Clin Cancer Res 2003, 9, 976-980.

8. Shah M.S., Begum M., Rahman M., Baqi S.M.A.: Disseminated herpes zoster in a patient with acute lymphoblastic leukaemia: a case study. Bangladesh Med Res Counc Bull 2018, 44, 60-63.

9. Mabuchi T., Yamaoka H., Kato M., Ikoma N., Tamiya S., Song H.J., et al.: Case of disseminated vesicles of herpes zoster developing one day before the onset of local eruption in a hospitalized immunocompromised patient. Tokai J Exp Clin Med $2013,38,52-54$

10. Shvartsbeyn M., Pandey S., Mercer S.E., Goldenberg G.: Leukemia cutis presenting clinically as disseminated herpes zoster in a patient with unrecognized acute promyelocytic leukemia. J Clin Aesthet Dermatol 2012, 5, 40-43.

11. Okuma H.S., Kobayashi Y., Makita S., Kitahara H., Fukuhara S., Munakata W., et al.: Disseminated herpes zoster infection initially presenting with abdominal pain in patients with lymphoma undergoing conventional chemotherapy: a report of three cases. Oncol Lett 2016, 12, 809-814.

12. Chen I., Fohtung R.B., Oughli H.A., Bauer R., Mattar C., Powderly W.G., et al.: Concurrent ramsay hunt syndrome and disseminated herpes zoster in a patient with relapsed chronic lymphocytic leukemia. IDCases 2016, 6, 79-82.

13. Kubota Y., Kosaka K., Hokazono T., Yamaji Y., Tezuka T., Akita S., et al.: Disseminated zoster in an adult patient with extensive burns: a case report. Virol J 2019, 16, 68.

14. Krishnaram A.S., Sachan Y., Rani G.G.: Co-reactivation of varicella zoster virus and herpes simplex virus with disseminated cutaneous lesions in a lymphoma patient. Indian J Dermatol Venereol Leprol 2013, 79, 709-711. 
15. O'Toole E.A., Mooney E.E., Walsh J.B., Sweeney J.B., Barnes L.: Disseminated herpes zoster in the elderly. Ir J Med Sci 1997, $166,141-142$

16. Willis E.D., Woodward M., Brown E., Popmihajlov Z., Saddier P., Annunziato P.W., et al.: Herpes zoster vaccine live: a 10 year review of post-marketing safety experience. Vaccine 2017, 35, 7231-7239.

Received: 6.05 .2021

Accepted: 5.06 .2021

Otrzymano: 6.05.2021 r.

Zaakceptowano: $5.06 .2021 \mathrm{r}$

How to cite this article

Artyszuk D., Rogowski M., Baran A., Flisiak I.: Disseminated herpes zoster in the course of chronic myeloid leukemia. Dermatol Rev/Przegl Dermatol 2021, 108, 194-201. DOI: https://doi.org/10.5114/dr.2021.108612. 